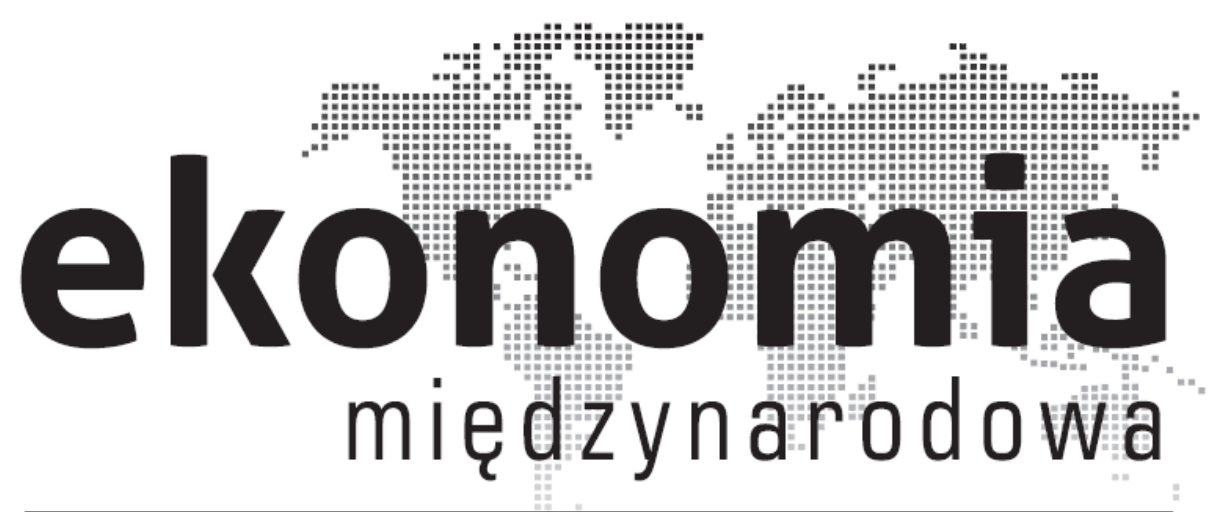

Ekonomia Międzynarodowa

Nr 14 (2016)

Wydawca: Uniwersytet Łódzki

(Publisher: University of Lodz)

www.ekonomia-m.pl

ISSN: 2082-4440 - wydanie papierowe (paper edition)

ISSN: 2300-6005 - wydanie elektroniczne (electronic edition)

Wersja elektroniczna czasopisma jest wersją referencyjną

(Electronic edition is the reference version of the journal)
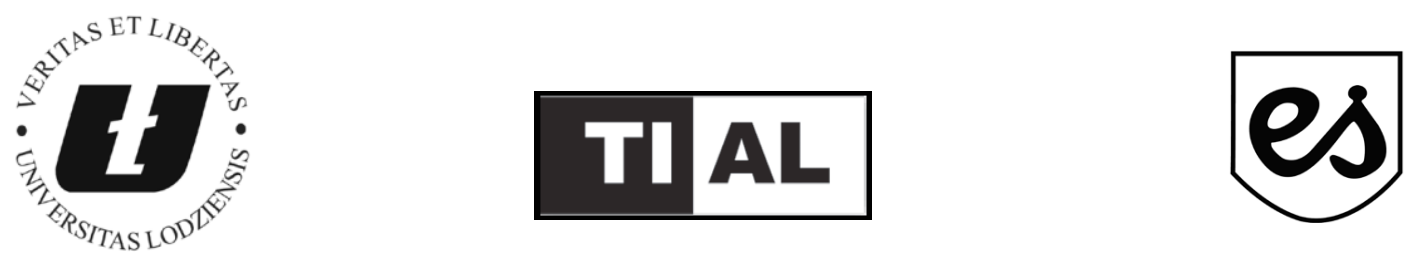


\section{Gender Pay Gap in Poland}

Jarosław Oczki*

\section{Introduction}

Inequalities in the labour market are common and are not necessarily the result of discrimination by employers. Gender inequalities can manifest themselves as: unequal pay, over-representation of men or women in selected sectors of the economy, unequal access to managerial positions, to training, typical employment arrangements, etc. A popular research area in the field of gender inequalities is analysis of the gender pay gap. Women typically earn less than men, on average. The lower wages of women can indicate that there is discrimination in the labour market, however, it does not have to be the case. In order to determine how justified the wage discrepancies are, the concept of the explained gender pay gap was introduced. The aim of the article is to make a comparison between the gender pay gap in Poland and other highly developed countries in the period 2007-2013 and to discuss the concept of the explained gender pay gap.

\section{Data sources on income and income inequality}

Income statistics are used in scientific research as a source of information about standard of living, inequality, social exclusion and poverty. A variety of datasets are used for analysing incomes. A majority of income statistics are based on household surveys, while others utilise administrative sources. Most countries gather income information from large sample household surveys carried out according to standardised international guidelines. Internationally harmonised data enable cross-country comparisons. Micro-level data can serve not only as a source of information about the level

\footnotetext{
*Jarosław Oczki - PhD, Nicolaus Copernicus University in Toruń, Faculty of Economic Sciences and Management, Department of Human Resource Management.
} 
of income, but also about the distribution of income among individuals in society. Distribution of income is a widely debated issue because it is related to such important social problems as poverty and the fairness of the distribution of wealth in a society.

In the article, data from EU-SILC (Statistics on Income and Living Conditions) and the International Labour Organization Global Wage Database have been used. EU-SILC is the most comprehensive dataset on income in the European Union countries. It is a source of comparative statistics on incomes before and after social transfers, income distribution, living conditions and social exclusion. The EU-SILC has been created in order to monitor the progress of individual countries, and the EU as a whole, towards key objectives in the area of social inclusion and social protection. Apart from member countries of the EU, the dataset covers: Norway, Iceland, Switzerland, Turkey and the Former Yugoslav Republic of Macedonia.

EU-SILC provides data not only on income, but also on other measures describing individuals' social situations, such as: housing, material deprivation, economic activity, health, demography and education.

The EU-SILC database gathers information about the following income variables (Eurostat 2015a):

1. total disposable household income;

2. total disposable household income before social transfers other than old age and survivor's benefits;

3. total disposable household income before social transfers including old age and survivor's benefits;

4. family/child related allowances;

5. housing allowances;

6. regular inter-household cash transfer received;

7. interest, dividends, profit from capital investments in unincorporated business;

8. interest repayments on mortgage.

One of the most commonly used categories of income in studies based on the EU-SILC database is equivalised disposable income. It is the total income of a household that is available to spend or save, divided by the number of household members converted into equivalised adults. Household members are made equivalent by applying a specific equivalence scale.

The ILO Global Wage Database - another comprehensive dataset on wages and incomes - in its section covering EU countries is based on EU-SILC.

The Gini coefficient is the most commonly used measure of income inequality. Its value for Poland in 2013 - 30.7 - was approx. at the same level as the EU average (Eurostat 2015c). In the period 2005-2013, a significant decline of the coefficient in Poland was recorded - from 35.6 to 30.7. This tendency could indicate that there was a decline in income inequality, however, there are some problems with the EU-SILC data quality for Poland, especially concerning 2005. Firstly, it is claimed that the value of the Gini coefficient in 2005 could have been overestimated due to methodological errors (OECD 2012). It is probable that 
the real income inequality in Poland in 2005 was substantially lower. Secondly, some authors argue that the methodology of the Polish Household Budget Survey (HBS) - a survey that supplies the EU-SILC dataset - can lead to bias. Myck and Najsztub (2015) claim that alternative methods of calibration of the HBS could be used and that they change the estimates of inequality measures significantly. The authors conducted analysis of representativeness of the HBS data for the years 2006-2011 and conclude that the weighing method used for calibration influences the estimates of income inequality, and the use of alternative methods leads to values of inequality significantly higher than those calculated on the basis of an existing dataset. Some researchers point out that tax office data can be a more trustworthy source of information about incomes than data from surveys (Kośny 2012). Wealthy people are less likely to participate in the surveys and the omission of this group in a survey leads to a bias in the distribution of declared incomes and an underestimation of income inequality.

\section{Gender pay gap}

The gender pay gap is defined as the difference in average wages between men and women and is usually calculated on an hourly basis, presented as a percentage of the difference between the gross salaries of men and women in the gross earnings of men. Men usually earn more than women (Goldin 2014), (Christofides, Polycarpou, Vrachimis 2013), (ILO 2015). To a certain extent, the lower level of income earned by women may suggest the presence of discrimination in the labour market. However, gender income disparities can be a result of other, non-discriminatory factors, in particular (Oczki 2014, 148):

1. smaller average amount of overtime worked by women and the higher representation of women in part-time work arrangements;

2. the concentration of women in sectors where wages are typically low, e.g. in education, health care, retail trade;

3. weaker, on average, determination of women in achieving a pay rise, lower wage expectations of women compared with men;

4. lower interest of women to fill top managerial positions in which it is harder to reconcile professional and family duties.

According to Eurostat (2015b), in 2013, the gender pay gap in Poland $-6.4 \%$ - was the third lowest in the European Union (Figure 1). In the period 2007-2013 it declined significantly - from almost $15 \%$, which made it the highest percentage decline in gender pay gap among all EU countries. In the whole of the EU, on average, women earned $16.4 \%$ less than men. The largest disparities - over $20 \%$-were recorded in Estonia, Austria, the Czech Republic and Germany, while the smallest were in Slovenia, Malta, Poland, Croatia and Italy. In some countries gender the pay gap has increased in the last several years - most significantly in Portugal and Italy. 
Figure 1. Gender pay gap in the EU countries in 2007 and 2013

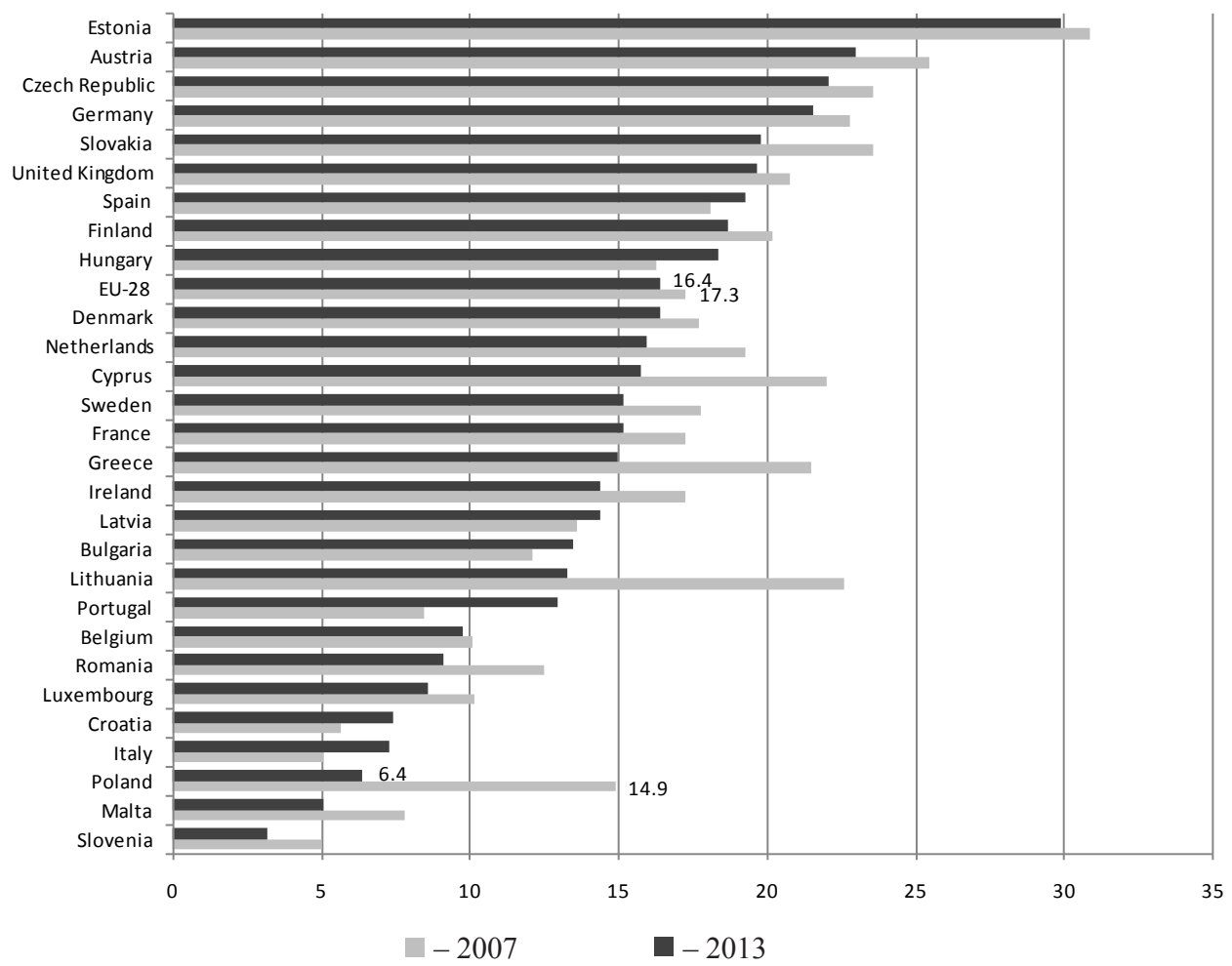

Source: Eurostat 2015b.

Data on disposable income after social transfers for 2013 also indicate that income disparities with regard to sex in Poland are small. Considering this category of income, gender inequality in Poland is one of the smallest in the European Union - average net disposable income of women was only $2.4 \%$ lower than the income of men. Moreover, in the population of under 60-year-olds, men had lower incomes than women - by $0.8 \%$. Also, when disposable income is measured by a median, not average, Poland is one of the three EU countries where women received higher incomes than men.

\section{Explained gender pay gap}

Analyses of wage inequalities between men and women are frequently based on explained, adjusted (as opposed to actual, observed) gender pay gap, i.e. measures which takes into account the differences in the individual characteristics of male and female employees, such as: education, age, work experience, etc. According to the International Labour Organisation, the adjusted pay gap can differ signifi- 
cantly from the actual value. The ILO identifies a number of significant variables which influence wage levels: education (four categories), work experience, sector of the economy, location of the employer (urban or rural), workload (weekly hours of work) and the type of job (managerial, requiring high, medium, low and minimum qualifications) (ILO 2015). After accounting for these factors, gender pay gaps in all countries analysed in the ILO report decrease, and in the case of some countries they even become negative (Figure 2). The negative value of the explained pay gap for Poland $(-4.1 \%)$, means that if the salaries of both sexes depended only on the above variables, women should earn $4.1 \%$ more than men, on average (e.g., because more women than men hold a university degree). For comparison, for the same year, the actual gender pay gap in Poland was $11.9 \%$, i.e., women achieved wages almost $12 \%$ lower than men.

Figure 2. Actual and explained gender pay gaps in selected countries - estimates for 2010*

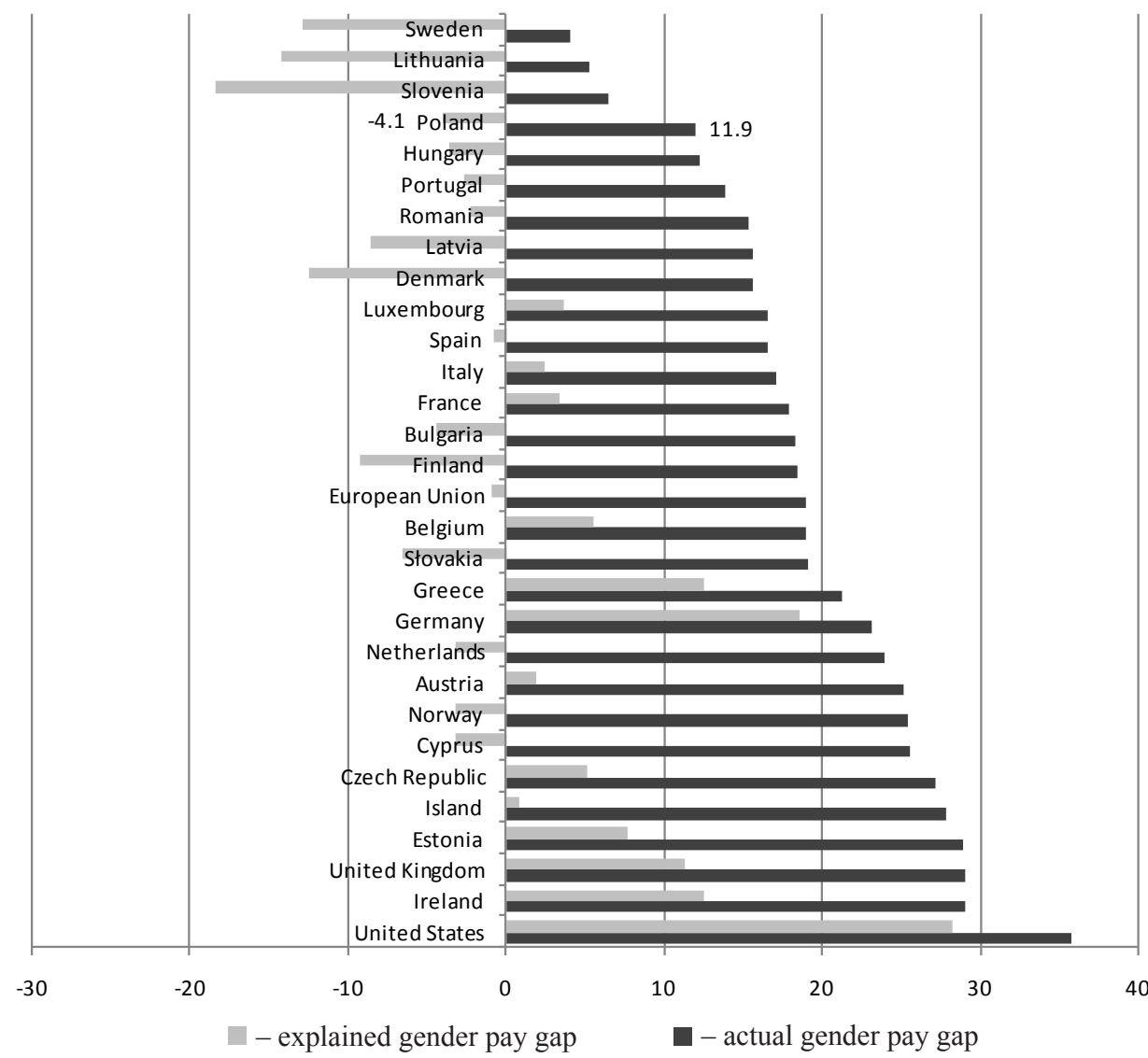

* At the time of preparing the article, the latest available estimates of the explained gender pay gap in presented countries were from 2010.

Source: ILO 2015: 49. 
The comparison of actual and explained values of the gender pay gap does not have to lead to the conclusion that there is a discrimination of women in the labour market. It cannot be assumed that a higher level of an individual's education measured merely by maximum formal educational degree completed, regardless of the field of study and specialisation, should always guarantee higher earnings. Wages offered by employers also depend on other factors than those included in the calculation of the explained gender pay gap, such as demand for employees holding not only a degree, but holding a degree in, e.g. mechanical engineering, IT, programming, etc. The demand in the Polish labour market for graduates of certain fields of study, in particular, social and pedagogical sciences and the humanities (in which women are overrepresented), is relatively small compared to their supply. On the other hand, one can observe a high demand for graduates, mostly male, of technical universities, and, in some sectors of the economy, for skilled workers with just a vocational education. Wage levels are a product of the interplay of supply and demand in the labour market, and, in some cases, the higher wages of male employees can be a result of their underrepresentation in traditionally low-wage sectors.

For a more precise estimate of the explained gender pay gap, any analysis should take into account the differences in the representation of men and women in typically male and female professions, as well as the supply and demand for particular jobs in the labour market. Olivetti and Petrongolo (2014) analyse the gender pay gap and emphasise the importance of the economic structure of the employment on wages of men and women. Cha and Weeden (2014) show that employees who are ready to work a large amount of overtime (mostly men) are, on average, preferred by employers and, as a result, earn more, not only in general, but also they enjoy higher pay rates per hour worked. Only inclusion of all relevant variables significantly influencing wages leads to reliable estimates of the explained gender pay gap and enables inference about the occurrence of gender discrimination in the labour market.

\section{Conclusions}

In all analysed countries, men earned more than women, on average. In Poland, the gender pay gap was especially low - the third lowest in the European Union. When disposable income after social transfers is considered, Polish women in the working age population achieved higher incomes than men in the same age group. According to an estimate of the explained gender pay gap by the International Labour Organization, Polish women should earn more than men, e.g. because more of them hold tertiary education degrees. However, the simple fact that the explained gender pay gap was smaller than its actual value does not necessarily mean that there is discrimination of women by employers. The explained gender 
pay gap published by the ILO does not account for some additional important variables influencing wages, such as: the specific educational profile of individual employees or the supply and demand of specific categories of employees in the labour market. For this reason, it cannot be treated as a "fully explained" pay gap.

\section{References}

Cha Y., Weeden K.A. (2014), Overwork and the Slow Convergence in the Gender Gap in Wages, "American Sociological Review", published online before print.

Christofides L.N., Polycarpou A., Vrachimis K. (2013), Gender Wage Gaps, 'Sticky Floors' and 'Glass Ceilings' in Europe, "Labour Economics", Vol. 21.

Eurostat (2015a), Description of Target Variables. Household Data, http://epp. eurostat.ec.europa.eu/portal/page/portal/income_social_inclusion_living_ conditions/documents/tab/Tab/Household\%20data\%20-\%20income.pdf (accessed: 10.06.2015).

Eurostat (2015b), Gender Pay Gap Statistics, http://ec.europa.eu/eurostat/statistics-explained/index.php/Gender_pay_gap_statistics.

Eurostat (2015c), Statistics on Income and Living Conditions, http://epp.eurostat. ec.europa.eu/portal/page/portal/microdata/eu_silc.

Goldin C. (2014), A Grand Gender Convergence: Its Last Chapter, "American Economic Review", Vol. 104, No. 4.

ILO (2015), ILO Global Wage Report 2014/2015. Wages and Income Inequality, Geneva.

Kośny M. (2012), Upper Tail of the Income Distribution in Tax Records and Survey Data: Evidence from Poland, article presented at 32nd International Association for Research in Income and Wealth Conference, Boston, USA.

Myck M., Najsztub M. (2015),Data and Model Cross-validation to Improve Accuracy of Microsimulation Results: Estimates for the Polish Household Budget Survey, "International Journal of Microsimulation", Vol. 8, Issue 1.

Oczki J. (2014), Nierówności na rynku pracy w Polsce [w:] B. Kłos, J. Szymańczak (red.), Nierówności społecznew Polsce, Biuro Analiz Sejmowych, Wydawnictwo Sejmowe, Warszawa.

OECD (2012), Income Distribution Data Review - Poland, OECD, Paris, www. oecd.org/els/soc/OECDIncomeDistributionDataReview-Poland.pdf.

OECD (2013), OECD Framework for Statistics on the Distribution of Household Income, Consumption and Wealth, Paris.

Olivetti C., Petrongolo B. (2014), Gender Gaps across Countries and Skills: Demand, Supply and the Industry Structure, "Review of Economic Dynamics", Vol. 17, Issue 4. 


\section{Summary}

The aim of the article is to investigate the actual and explained gender pay gaps in Poland in comparison with selected highly developed countries, and to discuss the factors determining wage disparities between men and women. Data from Eurostat EU-SILC and the International Labour Organization were used. The article concludes that the gender pay gap in Poland is relatively small and decreasing, and that estimates of the explained gender pay gap published by the International Labour Organization do not consider the influence of some important variables shaping wages.

Keywords: gender pay gap, inequality in the labour market, income data

\section{Streszczenie}

\section{Luka dochodowa ze względu na płeć w Polsce}

Celem artykułu jest analiza porównawcza rzeczywistej i skorygowanej luki płacowej w Polsce i wybranych krajach wysoko rozwiniętych oraz dyskusja na temat czynników wpływających na zróżnicowanie w wynagrodzeniach mężczyzn i kobiet. Wykorzystano dane Eurostatu EU-SILC oraz Międzynarodowej Organizacji Pracy. W artykule sformułowano wnioski o relatywnie niewielkiej i malejącej luce dochodowej ze względu na płeć w Polsce oraz o niewystarczającym zestawie zmiennych użytych do oszacowania skorygowanej luki dochodowej przez Międzynarodową Organizację Pracy.

Słowa kluczowe: luka dochodowa ze względu na płeć, nierówności na rynku pracy, dane o dochodach

JEL: J31 